\title{
Biocontrol capacity of wild and mutant Trichoderma harzianum (Rifai) strains on Rhizoctonia solani 618: effect of temperature and soil type during storage
}

\author{
Jaime Montealegre \\ Departamento de Sanidad Vegetal \\ Facultad de Ciencias Agronómicas \\ Universidad de Chile \\ Casilla 1004, Santiago, Chile \\ Luis Valderrama \\ Departamento de Sanidad Vegetal \\ Facultad de Ciencias Agronómicas \\ Universidad de Chile \\ Casilla 1004, Santiago, Chile \\ Rodrigo Herrera \\ Departamento de Sanidad Vegetal \\ Facultad de Ciencias Agronómicas \\ Universidad de Chile \\ Casilla 1004, Santiago, Chile \\ Ximena Besoaín \\ Laboratorio de Fitopatología \\ Facultad de Agronomía \\ Pontificia Universidad Católica de Valparaíso \\ Quilota, Chile \\ Luz M. Pérez* \\ Asesorías e Inversiones Biostrategy Limitada \\ Hernando de Aguirre 1372, Providencia \\ Santiago, Chile \\ Tel: 5622743176 \\ E-mail: biostrategy.perez2@gmail.com
}

Financial support: FONDECYT No. 1040531-04

Keywords: bioantagonism, persistence, root rot, tomato.

Abbreviations: cfu: colony forming units

PDA: Potato Dextrose Agar

Wild (Th11, Th12 and Th650) and mutant (Th11A80.1, Th12A40.1, Th12C40.1 and Th650-NG7) Trichoderma harzianum strains were stored for 180 days at $5^{\circ} \mathrm{C}$ or at $22^{\circ} \mathrm{C}$, in two types of soils. Strains recovered at 90, 120 and 180 days from the two types of soils, retained their full capacity to biocontrol Rhizoctonia solani 618 , that produces crown and root rot of tomatoes. Recovery, estimated as colony forming units (cfu) of the wild and mutant strains, showed that all increased their cfu after storage independently of the type of soil and temperature, although kinetic behavior differed among strains. Ratios of recovery after storage in type $B$ soil/ type A soil or at $22^{\circ} \mathrm{C} / 5^{\circ} \mathrm{C}$, higher or lower than one respectively, allowed to establish that Th11 and Th12 were the most appropriate strains for the biocontrol of
R. solani in conditions where growth of the phytopathogen is optimal.

Fungi belonging to the genus Trichoderma are important phytopathogen bioantagonists, acting especially against soil borne microorganisms such as Rhizoctonia solani that causes seedling wilt in several crops (Apablaza, 2000; Agrios, 2001; Latorre, 2004). Trichoderma can indirectly biocontrol phytopathogens by competing for space and nutrients, through the secretion of antibiotic volatiles and/or diffusible metabolites, which modify soil conditions promoting growth and plant defense mechanisms. On the other hand, mycoparasitism is considered a direct biocontrol mechanism (Howell, 2003; Benítez et al. 2004). Several native isolated Trichoderma strains have proved to

*Corresponding author 

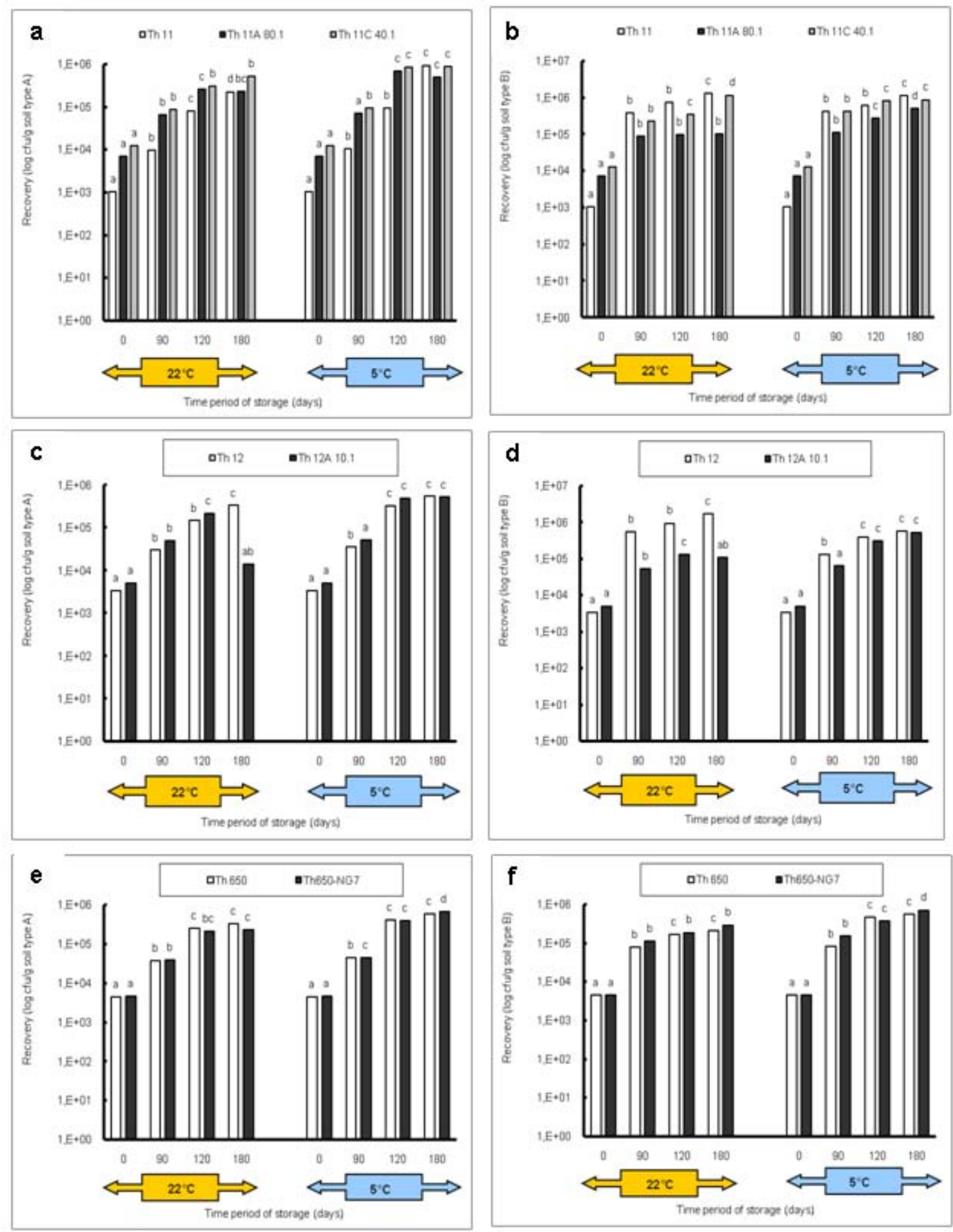

Figure 1. Time course recovery of wild and mutant Trichoderma harzianum strains after storage in type A soil (a, c, e), and in type B soil $(\mathbf{b}, \mathbf{d}, \mathbf{f})$ at two temperatures. Different letters within the same strain and condition mean significant differences after analysis of results by Tukey's test at $p \leq 0.5$.

be effective biocontrol agents against different phytopathogenic fungi (Benítez et al. 2004), and in addition, they could have a stimulatory effect on plant growth (Naseby et al. 2000). The obtainment of mutant strains has allowed improving biocontrol effectiveness, because of their higher secretion of enzymes involved in pathogen's cell wall degradation, such as chitinases and glucanases (Besoaín et al. 2007; Pérez et al. 2007). Both native and mutant strains of $T$. harzianum have proved to be effective in vivo biocontrol agents of $R$. solani that 
Temperature and soil type on Trichoderma harzianum biocontrol effectiveness

Table 1. Colony forming units (cfu)/g pellets of each $T$. harzianum strain.

\begin{tabular}{|c|c|c|c|}
\hline Type of strains & Strain & cfu / g pellets & cfu inoculated/vial \\
\hline & Th 12A 10,1 & 564,188 & 5,078 \\
\hline \multirow{2}{*}{ Mutant strains } & Th 11A 80,1 & 788,875 & 7,100 \\
\hline & Th 11C 40,1 & $1,038,813$ & 9,349 \\
\hline & Th650-NG7 & 511,156 & 4,600 \\
\hline Wild strains & Th 12 & 375,000 & 3,375 \\
\hline & Th 11 & 115,969 & 1,044 \\
\hline
\end{tabular}

causes crown and root rot in tomatoes (Pérez et al. 2007). The effectiveness of biocontrol agents depends on several parameters, that includes soil texture, water content, $\mathrm{pH}$ and crop history (Hagn et al. 2003; Berg et al. 2005); therefore their application should consider the environmental stress that could affect not only their survival in the soil, but also their ability to maintain their biocontrol capacity. The effect of low temperatures (Antal et al. 2000), water activity and pH (Kredics et al. 2000; Kredics et al. 2004; Begoude et al. 2007), or the presence of heavy metals, or pesticides or antagonistic bacteria (Kay and Stewart, 1994; Naár and Kecskés, 1998; Kredics et al. 2001) have been tested as stress factors that may affect wild or mutant biocontrol Trichoderma strains. Nevertheless, most of these studies have been run in in vitro conditions of the biocontrol agent.

Our group has obtained different mutants from the wild Trichoderma strains Th11, Th12 and Th650, which have been characterized related to their ability to secrete fungal cell wall degrading enzymes as well as their ability to control in vitro $R$. solani and other tomato pathogens (Besoaín et al. 2007; Pérez et al. 2007). Some of them have been also tested under greenhouse condition (Montealegre et al. 2009), but it is unknown whether these mutants could survive in different conditions. The present work describes the survival of wild and mutant strains of $T$. harzianum at two different temperatures and in two different types of soils, and if these conditions modify their biocontrol activity in vitro, on $R$. solani infecting tomato.

\section{MATERIALS AND METHODS}

\section{Microorganisms}

R. solani strain 618 (AG 4), and four T. harzianum mutants (Th650-NG7; Th11A80.1; Th11C40.1 and Th12A.10.1) and their corresponding parental strains (Th650, Th11 and
Th12) were used (Montealegre et al. 2003; Besoaín et al. 2007; Pérez et al. 2007).

\section{Soils}

Soils were obtained from: A) Antumapu Campus (Universidad de Chile, Santiago, Metropolitan Region), and B) Experimental Station La Palma (P. Universidad Católica de Valparaiso, V Region), Chile. The physical and chemical analysis, performed by the Institute of Agricultural Research - Chile (INIA) of both types of soils showed:

For type A soil (Antumapu): $12.8 \%$ sand, 46.4\% slime and $48.8 \%$ clay; $\mathrm{pH}=7.8$, conductivity $\left(\mathrm{mS} / \mathrm{cm}^{2}\right)=1.6$, organic material $=2.8 \%$, available $\mathrm{N}(\mathrm{mg} / \mathrm{Kg})=63$, available $\mathrm{P}$ $(\mathrm{mg} / \mathrm{Kg})=30$ and available $\mathrm{K}(\mathrm{mg} / \mathrm{Kg})=192$.

For type B soil (La Palma): 60.7\% sand, 21.1\% slime and $16.2 \%$ clay; $\mathrm{pH}=6.9$, conductivity $\left(\mathrm{mS} / \mathrm{cm}^{2}\right)=5.3$, organic material $=2.3 \%$, available $\mathrm{N}(\mathrm{mg} / \mathrm{Kg})=95$, available $\mathrm{P}$ $(\mathrm{mg} / \mathrm{Kg})=126$ and available $\mathrm{K}(\mathrm{mg} / \mathrm{Kg})=408$.

The two types of soils were used to run storage tests after steam sterilization $(2.5 \mathrm{~mL}$ distilled water was added to give enough humidity equivalent to field capacity of water absorption) for $20 \mathrm{~min}$ at $121^{\circ} \mathrm{C}$.

\section{Storage of Trichoderma in two types of soils at two temperatures}

Trichoderma strains, previously formulated as alginate pellets (Montealegre and Larenas, 1997) and including the addition of 200 ppm of the antibiotic Strepto Plus (ENCO) to prevent bacterial contamination, were analyzed for their fungal concentration per g of pellets. The number of colony forming units (cfu)/g pellets for each Trichoderma strain, determined as in Madigan et al. (2003) using Petri dishes 


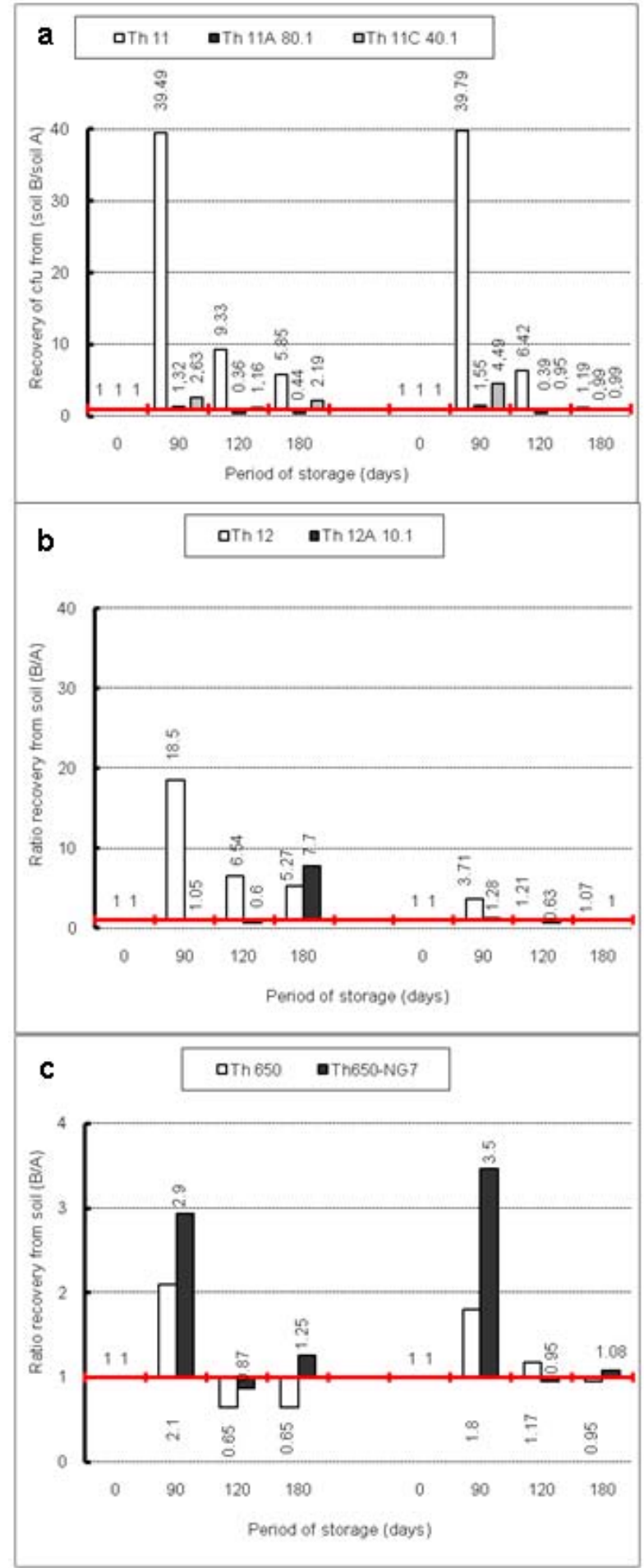

Figure 2. Ratio of recovery of $T$. harzianum strains from type B/type A soil after storage at $22^{\circ} \mathrm{C}$ and $5^{\circ} \mathrm{C}$.

containing potato dextrose agar (PDA, Difco) and incubation for 72 hrs at $22^{\circ} \mathrm{C}$, is shown in Table 1 . Pellets, containing an amount of cfu of the different strains, established as innocuous to tomato plants (Montealegre et al. 2009), were grinded and $9 \mathrm{mg}$ per vial were mixed with
$5 \mathrm{~mL}$ of sterile humid soil type A (Antumapu) or type B (La Palma). Vials were placed on trays in a random distribution and maintained at $22^{\circ} \mathrm{C}$ or at $5^{\circ} \mathrm{C}$ during 180 days. Only in the case of the experiment maintained at $22^{\circ} \mathrm{C}, 1 \mathrm{~mL}$ of sterile distilled water was added at 90 days. One g samples were taken from vials (quadruplicates) after 90, 120 and 180 days storage, and Trichoderma strains were re-isolated from $1 \times 10^{-3}-1 \times 10^{-5}$ dilutions, using a selective medium for $T$. harzianum (Williams et al. 2003). Four replicates were considered for each time period, for each Trichoderma strain, for each soil and for each temperature tested. Experiment was repeated two times.

Results correspond to the mean of samples taken at each period of storage under each condition, analyzed by the Tukey's test at $\mathrm{p} \leq 0.05$, including data from the two experiments run, and are reported in a semilog plot as log $\mathrm{cfu}^{-1}$ soil vs period of storage.

Also, results (as cfu $\mathrm{g}^{-1}$ soil) were used to calculate the following ratios of recovery of the $T$. harzianum strains: a) between the two types of soils (cfu g ${ }^{-1}$ soil type B / $\mathrm{cfu} \mathrm{g}^{-1}$ soil type A), and b) between the two temperatures used for storage (cfu g ${ }^{-1}$ at $22^{\circ} \mathrm{C} / \mathrm{cfu} \mathrm{g}^{-1}$ soil at $5^{\circ} \mathrm{C}$ ).

\section{Biocontrol activity of $T$. harzianum strains after storage in two types of soils at two different temperatures}

Strains recovered from soils after 90, 120 and 180 days storage at $22^{\circ} \mathrm{C}$ or at $5^{\circ} \mathrm{C}$ in the two types of soils (A: Antumapu and B: La Palma) were used to test the "in vitro" direct antagonism against $R$. solani strain 618 as in Arias et al. (2006). Briefly, Petri dishes containing PDA at pH 6.5 were seeded with $5 \mathrm{~mm}$ disks containing mycelia from the phytopathogen and from each biocontrol agent at $4 \mathrm{~cm}$ distance between them, and equidistant from the center of the dish. Dishes were incubated at $22^{\circ} \mathrm{C}$. Controls were run using disks solely of the phytopathogen or of the biocontrol agent. Inhibition of radial growth (IRG) was estimated once control dishes containing the phytopathogen, were completely covered by the fungal mycelia, using the formula developed by Dennis and Webster (1971). Two different experiments were run, considering seven treatments with five replicas each one. The experimental unit was one Petri dish. Results, obtained as percentage, were modified through the Bliss angular transformation, and a variance analysis was performed. When significant differences were detected, the Tukey's test was used at $\mathrm{p} \leq$ 0.05 .

\section{RESULTS}

The comparison between the initial inoculum and the recovery of the wild Trichoderma strains Th11, Th12 and Th650 and their derived mutants Th11A80.1, Th11C40.1, Th12A10.1 and Th650-NG7, showed an increase in the number of cfu after storage for most of the strains (Table 2). In general, the increases in cfu were observed both in 
Table 2. Times growth ${ }^{1}$ of Trichoderma harzianum strains in type $A(a)$ and type $B(b)$ soil at $22^{\circ} \mathrm{C}$ and $5^{\circ} \mathrm{C}$.

\begin{tabular}{|c|c|c|c|c|c|c|c|c|}
\hline \multirow{2}{*}{ (a) } & \multirow{2}{*}{ Days } & \multicolumn{4}{|c|}{ Mutant strains } & \multicolumn{3}{|c|}{ Wild strains } \\
\hline & & Th $12 \mathrm{~A} 10.1$ & Th 11A 80.1 & Th 11C 40.1 & Th650-NG7 & Th 12 & Th 11 & Th 650 \\
\hline \multirow{3}{*}{$22^{\circ} \mathrm{C}$} & 90 & 9.8 & 9.3 & 9.4 & 8.3 & 8.7 & 9.3 & 8.4 \\
\hline & 120 & 41.8 & 36.9 & 32.4 & 46.8 & 43.0 & 77.6 & 57.3 \\
\hline & 180 & 2.8 & 32.1 & 56.5 & 50.4 & 97.8 & 216.5 & 72.7 \\
\hline \multirow{3}{*}{$5^{\circ} \mathrm{C}$} & 90 & 10.0 & 10.0 & 10.0 & 9.7 & 10.4 & 10.0 & 10.1 \\
\hline & 120 & 96.3 & 97.1 & 91.1 & 84.2 & 95.1 & 91.0 & 90.8 \\
\hline & 180 & 101.2 & 71.0 & 95.0 & 143.5 & 158.2 & 896.6 & 130.7 \\
\hline \multirow{2}{*}{ (b) } & \multirow{2}{*}{ Days } & \multicolumn{4}{|c|}{ Mutant strains } & \multicolumn{3}{|c|}{ Wild strains } \\
\hline & & Th 12A 10.1 & Th 11A 80.1 & Th 11C 40.1 & Th650-NG7 & Th 12 & Th 11 & Th 650 \\
\hline \multirow{3}{*}{$22^{\circ} \mathrm{C}$} & 90 & 10.3 & 12.3 & 24.6 & 24.4 & 161.5 & 368.8 & 17.5 \\
\hline & 120 & 25.5 & 13.5 & 37.4 & 40.7 & 281.5 & 724.1 & 37.0 \\
\hline & 180 & 21.3 & 14.1 & 123.9 & 63.5 & 515.0 & 1266.3 & 47.1 \\
\hline \multirow{3}{*}{$5^{\circ} \mathrm{C}$} & 90 & 12.8 & 15.5 & 44.9 & 33.7 & 38.5 & 397.5 & 18.2 \\
\hline & 120 & 61.0 & 38.0 & 86.6 & 80.4 & 115.6 & 584.3 & 106.6 \\
\hline & 180 & 101.2 & 70.1 & 93.7 & 154.8 & 169.5 & 1069.0 & 124.8 \\
\hline
\end{tabular}

1/ Times growth represents [cfu/g soil recovered at each period of storage/ cfu inoculated into vials].

type A and type B soils, at different time periods and at different temperatures of storage, conditions that did not changed the ability of any of the strains to inhibit the development of $R$. solani (Table 3). However, several differences in specific recovery patterns were observed.

\section{Th11, Th11A80.1 and Th11C40.1}

Th11, Th11A80.1 and Th11C40.1 showed a continuous increase in cfu during all the time period of storage at $22^{\circ} \mathrm{C}$ and at $5^{\circ} \mathrm{C}$ both in soils type $\mathrm{A}$ and $\mathrm{B}$ (Figure 1a; Figure 1b). These showed specific kinetics of growth where Th11 reached 216.5 the initial inoculum, 6.7 and 3.8 fold higher than the obtained for Th11A80.1 and ThC40.1 in soil type A, respectively (Table 2a). A similar behavior was observed in type B soil, where higher differences were obtained (Table 2b).

The ratio of recovery calculated as $\mathrm{cfu}^{-1}$ from soil type B/ $\mathrm{cfu} \mathrm{g}^{-1}$ from soil type A at $22^{\circ} \mathrm{C}$ (Figure 2a) was higher than one for Th11 and Th11C40.1 at all the periods of storage, while Th11A80.1 showed ratios lower than one at 120 and 180 days of storage. Ratios higher than one represent the ability of Th11 and Th11C40.1 to develop better in type B than in type A soil at the same temperature. On the other hand, Th11A80.1 that showed a ratio lower than one develops better in type $\mathrm{A}$ than in type $\mathrm{B}$ at $22^{\circ} \mathrm{C}$. When temperature was of $5^{\circ} \mathrm{C}$, ratios lower than one were obtained along all the time period of storage only for Th11. Ratios of recovery of Th11A801.1 and of Th11C40.1 trended to one after 120 days storage, suggesting that both Th11 mutants develop similarly in both types of soils at $5^{\circ} \mathrm{C}$.

The ratio of recovery between $22^{\circ} \mathrm{C}$ and $5^{\circ}$ was also calculated, in order to provide more information on the effect of temperature in the growth of each strain. Th11, Th11A80.1 and Th11C40.1 showed ratios of recovery $22^{\circ} \mathrm{C} / 5^{\circ} \mathrm{C}$ lower than one in type A soil (Figure 3a), suggesting that their development is better in this type of soil at $5^{\circ} \mathrm{C}$. This same type of behavior was observed only for Th11A80.1 in type B soil, because Th11 and 


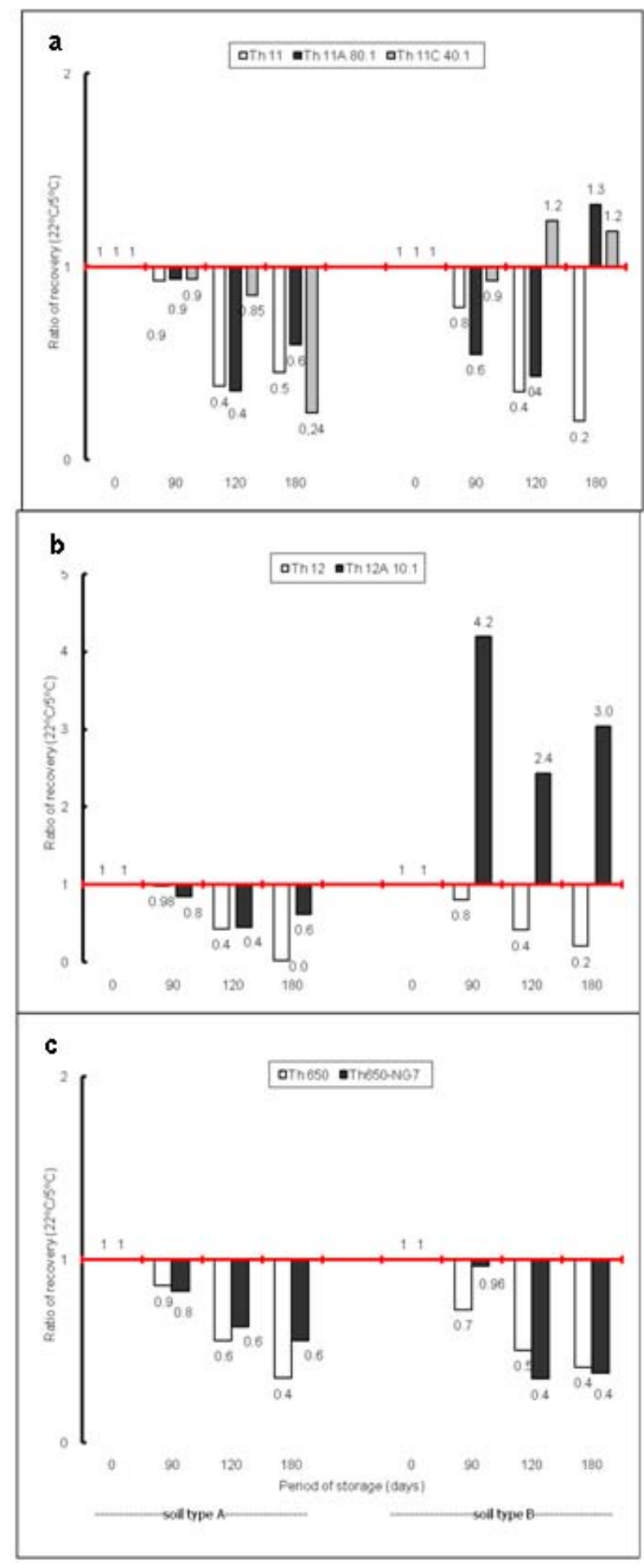

Figure 3. Ratio of recovery at $22^{\circ} \mathrm{C} / 5^{\circ} \mathrm{C}$ of $T$. harzianum strains after storage in two types of soils.

Th11C40.1 showed no dependence on temperature in this soil, as reflected in ratios closed to one.

\section{Th12 and Th12A10.1}

The wild Trichoderma strain Th12, stored in type A or type B soil, at $22^{\circ} \mathrm{C}$ or at $5^{\circ} \mathrm{C}$, showed an increase in recovery at all time periods tested (Figure 1c; Figure 1d). These showed specific kinetics of growth where Th12 and Th12A10.1 reached 43.0 and 41.8 fold the original inoculum at 120 days storage in type A soil, but where Th12 reached 34.9 fold the cfu $\mathrm{g}^{-1}$ soil of the mutant at day 180 (Table 2A). Th12 also showed better development than the mutant in type B soil, reaching 24.2 fold the $\mathrm{cfu} \mathrm{g}^{-1}$ soil of the mutant at day 180 (Table 2B).

Recovery of Th12 from type B soil was higher than from type A soil, as reflected in ratios values higher than one in all the period of storage at $22^{\circ} \mathrm{C}$ (Figure $2 \mathrm{~b}$ ). However, recovery at $5^{\circ} \mathrm{C}$ showed ratios that trended to one after 120 days storage, suggesting that development at this low temperature was independent of the type of soil, as was observed for Th11 (Figure 2a). Comparison of development at $22^{\circ} \mathrm{C} / 5^{\circ} \mathrm{C}$ showed that ratios were lower than one for type A soil, but were higher than one in type B soil (Figure 3b).

On the other hand, the mutant Th12A10.1 showed a maximal recovery after storage at $22^{\circ} \mathrm{C}$ in soil type $\mathrm{A}$ and $\mathrm{B}$ at 120 days, with a significant decrease at day 180 (Figure 1c; Figure 1d), while storage at $5^{\circ} \mathrm{C}$ resulted in an increase of cfu g ${ }^{-1}$ soil with no significant differences in recovery after day 120 (Figure 1c; Figure 1d). Recovery of Th12A10.1 from soil type B was higher than from soil type A at days 90 and 180 at $22^{\circ} \mathrm{C}$, reflected in ratios higher than one (Figure $2 \mathrm{~b}$ ), while ratios of recovery at $5^{\circ} \mathrm{C}$ trended to one after 120 days storage. Th12A 10.1 recovery at $5^{\circ} \mathrm{C}$ in any type of soil was higher than that at $22^{\circ} \mathrm{C}$ (Figure $3 \mathrm{~b}$ ).

\section{Th650 and Th650-NG7}

These wild and mutant strains showed similar growth patterns in both types of soils and at $22^{\circ} \mathrm{C}$ and $5^{\circ} \mathrm{C}$ (Figure 1e; Figure 1f). Kinetics of growth showed that they reached similar cfu g ${ }^{-1}$ soil were the wild strain population was 1.4 and 0.7 fold higher than the mutant in soil type A and soil type B, respectively (Table 2a; Table $2 \mathrm{~b}$ ).

Recovery of Th650 changed from soil type B at day 90 , to soil type $\mathrm{A}$ at days 120 and 180 at $22^{\circ} \mathrm{C}$ (Figure 2c), showing this change a delay to day 180 when storage was done at $5^{\circ} \mathrm{C}$. These results suggest that Th650 could adapt its growth to a soil with a $\mathrm{pH}$ (7.2) higher than that of its isolation soil ( $\mathrm{pH} 7.0)$. Th650 and Th650-NG7 recovery was better when stored at $5^{\circ} \mathrm{C}$ than at $22^{\circ} \mathrm{C}$, independently of the type of soil (Figure 3c).

\section{DISCUSSION}

The kinetic pattern of recovery of almost all the $T$. harzianum strains tested in this work at concentrations (Table 1) that were established to be innocuous to tomato plants (Montealegre et al. 2009), is similar when compared among them, with the exception of Th12A10.1 (Figure 1). This mutant, that showed a significant decrease in cfu recovered at day 180 when stored at $22^{\circ} \mathrm{C}$ was obtained after UV-A treatment of Th12 and showed no growth 
differences with the parental strain at $15^{\circ}$ in PDA plates (Besoaín et al. 2007). However, that same development was not reproduced when it was inoculated in the soil, suggesting that the mutant could have lost the parental ability to continue developing in the soil for time periods longer than 120 days. This fact allows to suggest its use in short time treatments and to discard its use in single dose at least for long time treatments. Nevertheless, a frequent replenishing of the biocontrol agent could be considered in this last situation.
The high recovery of all Trichoderma strains tested in this work, differ from that reported for $T$. harzianum strains collected in Egypt and inoculated in clay -loamy soil as conidia-containing alginate pellets (Shaban and El-Komy, 2000). Their kinetics of recovery showed that the populations remained constant and almost identical to the inoculum up to 30 days incubation at room temperature, decreasing to $0.1 \%$ of the initial inoculum at day 90 . Differences with our results could be explained on the different Trichoderma strains and type of soils used for

Table 3. Percent ${ }^{1}$ inhibition of $R$. solani radial growth by $T$. harzianum mutant and wild strains recovered from soils type $A$ and $B$ stored at $5^{\circ} \mathrm{C}(\mathrm{a})$ and at $22^{\circ} \mathrm{C}(\mathrm{a})$.

\begin{tabular}{|c|c|c|c|c|c|c|c|c|}
\hline \multirow{2}{*}{ (a) } & \multirow{2}{*}{ Days } & \multicolumn{4}{|c|}{ Mutant Strains } & \multicolumn{3}{|c|}{ Wild Strains } \\
\hline & & Th $12 \mathrm{~A} 10.1$ & Th 11A 80.1 & Th 11C 40.1 & $\mathrm{Th}_{650}$-NG 7 & Th 12 & Th 11 & Th 650 \\
\hline \multirow{8}{*}{$\begin{array}{l}\text { Type } \\
\text { B } \\
\text { soil } \\
\text { Type } \\
\text { A soil }\end{array}$} & $0^{2}$ & $52.55 \mathrm{a}$ & $53.89 \mathrm{a}$ & $54.75 \mathrm{a}$ & $50.32 \mathrm{a}$ & $52.96 \mathrm{a}$ & $48.55 \mathrm{a}$ & $54.92 \mathrm{a}$ \\
\hline & 90 & $52.49 \mathrm{a}$ & $54.42 \mathrm{a}$ & $54.81 \mathrm{a}$ & $49.51 \mathrm{a}$ & $53.51 \mathrm{a}$ & $47.58 \mathrm{a}$ & $55.25 \mathrm{a}$ \\
\hline & 120 & $52.74 \mathrm{a}$ & $54.56 \mathrm{a}$ & $55.07 \mathrm{a}$ & $50.95 \mathrm{a}$ & $53.57 \mathrm{a}$ & $48.03 \mathrm{a}$ & $55.37 \mathrm{a}$ \\
\hline & 180 & $53.15 \mathrm{a}$ & $54.09 \mathrm{a}$ & $54.86 \mathrm{a}$ & $51.00 \mathrm{a}$ & $52.56 \mathrm{a}$ & $49.09 \mathrm{a}$ & $54.75 \mathrm{a}$ \\
\hline & $0^{2}$ & $50.21 \mathrm{a}$ & $52.32 \mathrm{a}$ & $51.45 \mathrm{a}$ & $47.87 \mathrm{a}$ & $50.98 \mathrm{a}$ & $48.51 \mathrm{a}$ & $54.80 \mathrm{a}$ \\
\hline & 90 & $50.41 \mathrm{a}$ & $52.46 \mathrm{a}$ & $50.95 \mathrm{a}$ & $49.47 \mathrm{a}$ & $52.68 \mathrm{a}$ & $47.71 \mathrm{a}$ & $55.30 \mathrm{a}$ \\
\hline & 120 & $49.54 \mathrm{a}$ & $52.38 \mathrm{a}$ & $50.95 a$ & $50.92 \mathrm{a}$ & $51.83 \mathrm{a}$ & $48.27 \mathrm{a}$ & $54.50 \mathrm{a}$ \\
\hline & 180 & $49.82 \mathrm{a}$ & $50.80 \mathrm{a}$ & $51.86 \mathrm{a}$ & $48.78 \mathrm{a}$ & $53.93 \mathrm{a}$ & $49.09 \mathrm{a}$ & $56.79 \mathrm{a}$ \\
\hline
\end{tabular}

\begin{tabular}{|c|c|c|c|c|c|c|c|c|}
\hline \multirow{2}{*}{ (b) } & \multirow{2}{*}{ Days } & \multicolumn{4}{|c|}{ Mutant Strains } & \multicolumn{3}{|c|}{ Wild Strains } \\
\hline & & Th 12A 10.1 & Th 11A 80.1 & Th 11C 40.1 & Th $_{650}$-NG 7 & Th 12 & Th 11 & Th 650 \\
\hline \multirow{4}{*}{$\begin{array}{l}\text { Type } \\
\text { A } \\
\text { soil }\end{array}$} & $0^{2}$ & $50.21 \mathrm{a}$ & $50.22 \mathrm{a}$ & $52.35 \mathrm{a}$ & $51.14 \mathrm{a}$ & $51.42 \mathrm{a}$ & $52.20 \mathrm{a}$ & $51.88 \mathrm{a}$ \\
\hline & 90 & $49.96 \mathrm{a}$ & $50.34 \mathrm{a}$ & $50.64 \mathrm{a}$ & $50.74 \mathrm{a}$ & $50.94 a$ & $51.81 \mathrm{a}$ & $52.94 \mathrm{a}$ \\
\hline & 120 & $49.53 \mathrm{a}$ & $50.24 \mathrm{a}$ & $54.49 \mathrm{a}$ & $50.78 \mathrm{a}$ & $51.94 \mathrm{a}$ & $51.45 \mathrm{a}$ & $51.94 \mathrm{a}$ \\
\hline & 180 & $52.69 \mathrm{a}$ & $49.77 \mathrm{a}$ & $53.88 \mathrm{a}$ & $50.32 \mathrm{a}$ & $50.34 \mathrm{a}$ & $50.73 \mathrm{a}$ & $53.72 \mathrm{a}$ \\
\hline \multirow{4}{*}{$\begin{array}{r}\text { Type } \\
\text { B } \\
\text { soil }\end{array}$} & $0^{2}$ & $52.80 \mathrm{a}$ & $55.98 \mathrm{a}$ & $58.64 \mathrm{a}$ & $53.42 \mathrm{a}$ & $56.65 \mathrm{a}$ & $54.38 \mathrm{a}$ & $59.74 \mathrm{a}$ \\
\hline & 90 & $53.81 \mathrm{a}$ & $56.28 \mathrm{a}$ & $59.87 \mathrm{a}$ & $54.38 \mathrm{a}$ & $58.15 \mathrm{a}$ & $52.95 \mathrm{a}$ & $60.20 \mathrm{a}$ \\
\hline & 120 & $54.03 \mathrm{a}$ & $56.55 \mathrm{a}$ & $57.12 \mathrm{a}$ & $54.19 \mathrm{a}$ & $57.29 \mathrm{a}$ & $51.85 \mathrm{a}$ & $58.56 \mathrm{a}$ \\
\hline & 180 & $54.06 \mathrm{a}$ & $56.57 \mathrm{a}$ & $57.47 \mathrm{a}$ & $54.44 \mathrm{a}$ & $55.97 \mathrm{a}$ & $55.44 \mathrm{a}$ & $56.73 \mathrm{a}$ \\
\hline
\end{tabular}

$1 /$ Data in percent were obtained using the Dennis and Webster (1971) formula and the angular Bliss transformation. Identical letters in columns mean that there are no significant differences after statistical analysis using ANDEVA.

${ }^{2} /$ Controls of $\%$ inhibition of $R$. solani radial growth by mutant and wild $T$. harzianum strains were run after inoculation of vials and before storage. 
experiments, because formulations did not differ significantly.

The differences in recovery between Th11, Th12 and their derived-mutant strains (Figure 1a; Figure1b; Figure1c; Figure 1d and Table 2) may reflect changes produced in genomes by UV-A or UV-C which resulted in diverse ability to colonize soils by the mutants (Liu et al. 2008). The study of the development of wild Trichoderma strains in soils with different organic content has shown that the different concentrations did not have any effect on Trichoderma development (Hagn et al. 2003), thus supporting the fact that nutritional compounds other than organic and/or mutations would be affecting the recovery of the strains tested in this work. On the other hand, higher recoveries of Th11 and Th12 could be associated to adaptations to specific nutritional compounds found in these soils, that could have led to the development of more diverse genetically changes in $T$. harzianum than those that can be observed solely from phenotypic characters (Druzhinina et al. 2006). In addition, the maintenance of the humidity of soils has proved to be important for the increase in cfu of the biocontrol agent (Orr and Knudsen, 2004), as in our experiments.

The $\mathrm{cfu} \mathrm{g}^{-1}$ soil recovered of each Trichoderma at day 180 compared to the initial inoculum (Table 2) differed among strains stored at $22^{\circ} \mathrm{C}$ or at $5^{\circ} \mathrm{C}$, in type A or type B soil, although in most cases the wild $T$. harzianum strains increased their population several times more than their corresponding mutants. The wild Trichoderma strain Th11, which has shown a good biocontrol activity on Pyrenochaeta lycopersici (Pérez et al. 2002), a pathogen where temperature influences the development of corky root in tomato plants (Shishkoff and Campbell, 1990), showed the highest recovery in this low temperature of storage, reaching 896.6 and 1,069 fold its initial inoculum in soil $\mathrm{A}$ and $\mathrm{B}$, respectively (Table 2). In general, the recovery of strains stored at $5^{\circ} \mathrm{C}$ was significantly higher than the recovery of strains stored at $22^{\circ} \mathrm{C}$, suggesting that in this last condition it was not due to lack of nutrients in the soil or to competition for space because of a high population of microorganisms, but due to an effect of heat affecting the growth rate and/or the survival in the soil at this temperature. These results agree with those obtained by Küçük and Kivanç (2005) where the recovery of different Trichoderma strains correlated well with temperature, thus accounting for a higher recovery at lower temperatures. In addition, these authors were able to recover fungal colonies after 24 weeks storage at $4^{\circ} \mathrm{C}$. The effect of high temperatures on Trichoderma storage was also tested by Küçük and Kivanç (2005), but they were unable to recover colonies after six weeks storage at $30^{\circ} \mathrm{C}$. On the opposite, experiments run with alginate encapsulated mycelia showed that radial $T$. harzianum (ThzID1) development was better when inoculated in slit loamy soil and incubated during 14 days at $24^{\circ} \mathrm{C}$ than at $15^{\circ} \mathrm{C}$ (Knudsen and Bin, 1990). Their differences with our results could be explained on the different Trichoderma strains and type of soils used for experiments, because formulations did not differ significantly. On the other hand, tests run with the TH-203 strain of $T$. harzianum inoculated in a sandy soil (consisting of $88-9 \%$ sand, 5-6\% silt, 4-9\% clay and 0-6\% organic matter, pH 5.95, with a moisture holding capacity of 10$2 \%$ ), showed the ability to develop 14.3 fold after 21 days incubation at $26-30^{\circ} \mathrm{C}$ (Strashnow et al. 1985), supporting again that results depend both in the strain and in the type of soil.

In addition, the increases in $\mathrm{cfu} \mathrm{g}^{-1}$ soil observed at $5^{\circ} \mathrm{C}$ higher than at $22^{\circ} \mathrm{C}$ (Table 2), suggest that formulations containing the strains tested in this work retain full viability at low temperatures, being this a good alternative for storage as has been already reported (Küçük and Kivanç, 2005). In addition, the temperature and soil-dependent growth increases in $\mathrm{cfu} \mathrm{g}^{-1}$ could be also valuable to discuss the use of these biocontrol agents in a future, considering temperature changes due to global warming (Ghini et al. 2008).

The ratio of $\mathrm{cfu} \mathrm{g}^{-1}$ soil type $\mathrm{B} / \mathrm{cfu} \mathrm{g}^{-1}$ soil type $\mathrm{A}$ higher than one obtained for Th11 and Th12 at $22^{\circ} \mathrm{C}$ and $5^{\circ} \mathrm{C}$ (Figure 2) indicate that these strains develop better in type B soil, site from where they were initially isolated to test their biocontrol effect on P. lycopersici (Pérez et al. 2002). In addition, a ratio higher than one obtained for the recovery of Th11 and Th12 at $22^{\circ} \mathrm{C} / 5^{\circ} \mathrm{C}$ (Figure 3) indicate that these strains develop better at $22^{\circ} \mathrm{C}$, also the optimal temperature for $R$. solani development (Arias et al. 2006). Therefore, based on these ratios and on the fact that Th11 and Th12 retained their full ability to control $R$. solani development (Table 3), it may be suggested their use for the control of this phytopathogen in field conditions. Th11C40.1 obtained after UV-C irradiation of Th11 (Besoaín et al. 2007) retained in part the characteristics of Th11 because it showed ratios higher than one when comparing development in soil B/soil A (Figure 2a), but lower than one when comparing recovery at $22^{\circ} \mathrm{C} / 5^{\circ} \mathrm{C}$ (Figure 3a), while Th11A80.1 did not show growth characteristics similar to its parental strain in these conditions (Figure 2a; Figure 3a). Nevertheless, and although mutation could have altered the ability of these mutants to develop as Th11, UV irradiation did not modify their inhibitory effect on $R$. solani growth (Table 3 ). On the other hand, Th12A10.1 increased at later time periods of storage its ability to develop in type B soil at $22^{\circ} \mathrm{C}$ (Figure $2 \mathrm{~b})$, as reflected by a ratio higher than one, but $5^{\circ} \mathrm{C}$ resulted to be a better temperature for its development, as reflected by ratios lower than one when comparing recovery at $22^{\circ} \mathrm{C} / 5^{\circ} \mathrm{C}$ in both types of soils (Figure $3 \mathrm{~b}$ ), suggesting that UV-A mutation could have altered its development.

Development of Th650 and Th650-NG7 showed ratios of recovery soil type $\mathrm{B} /$ soil type $\mathrm{A}$ higher than one only at 90 days storage at $22^{\circ} \mathrm{C}$ or at $5^{\circ} \mathrm{C}$ (Figure 2c) because ratios were closer to one at longer time periods. Also, ratios of recovery at $22^{\circ} \mathrm{C} / 5^{\circ} \mathrm{C}$ were lower than one for these strains in both types of soils (Figure 3c), suggesting that the 
chemical treatment used for the obtainment of Th650-NG7 (Pérez et al. 2007) did not modify, at least from these aspects, the characteristics of the parental strain. Moreover, the mutant and parental strain retained their inhibitory effect on $R$. solani development (Table 3).

Ratios of recovery lower than one at $22^{\circ} \mathrm{C} / 5^{\circ} \mathrm{C}$ of both wild and mutant strains in the types of soils tested (Figure 3), along with a high recovery (Table 2) suggest that these could be used for the biocontrol of phytopathogens that attack tomato plants in the winter season, as has been described for Th11 and Th12 on P. lycopersici (Pérez et al. 2002).

The different mutant Trichoderma strains recovered at different time periods of storage in two types of soils at $22^{\circ} \mathrm{C}$ or $5^{\circ} \mathrm{C}$, maintained their biocontrol capacity on $R$. solani 618 (Table 3), as reported for the parental strains (Arias et al. 2006; Montealegre et al. 2007). These results suggest that soil physical and chemical differences as well as low and high temperatures do not change the biocontrol capacity of the Trichoderma strains tested, and therefore they may be used within a wide range of temperatures and in types of soils similar to those tested in this work. The efficiency of Trichoderma strains has been tested on other phytopathogens (Haggag and Amin, 2001), where combinations of different strains in field conditions with analysis of the decrease in the cfu $\mathrm{g}^{-1}$ soil of Fusarium solani has been recorded, without including the biocontrol effect of recovered Trichoderma strains on the fungus.

It may be concluded that the permanence in the soil and the maintenance of the biocontrol activity by all wild and the mutant $T$. harzianum strains tested in this work after storage at different temperatures and in different types of soils up to three months, not only contributes to the understanding of the behavior of these fungi in conditions similar to those occurring in nature but also provides the basis for a practical use of them at the field level.

\section{REFERENCES}

AGRIOS, G. Phytopathology. $2^{\text {nd }}$ Ed. México; Limusa S.A., 2001. 838 p.

ANTAL, Z.; MACZINGER, L.; SZAKÁCS, G.; TENGERDY, R.P. and FERENCZY, L. Colony growth, in vitro antagonism and secretion of extracellular enzymes in cold-tolerant strains of Trichoderma species. Mycological Research, May 2000, vol. 104, no. 5, p. 545-549.

APABLAZA, Gastón E. Patología de cultivos, epidemiología y control holístico. Santiago; Ediciones Universidad Católica de Chile, 2000. 347 p. ISBN 956140561X

ARIAS, Mauricio; HERRERA, Rodrigo; BESOAÍN, Ximena; PÉREZ, Luz María and MONTEALEGRE, Jaime. In vitro evaluation of Trichoderma strains mutant for the control of Rhizoctonia solani and Phytophthora nicotianae in tomatoes. Boletín Micológico, 2006, vol. 21, p. 71-75.

BEGOUDE, B.A.D.; LAHLALI, R.; FRIED, D.; TONDJE, P.R. and JIJAKLI, M.H. Response surface methodology study on the combined effects of temperature, $\mathrm{pH}$ and water activity on the growth rate of Trichoderma asperellum. Journal of Applied Microbiology, October 2007, vol. 103, no. 4, p. 845-854.

BENÍTEZ, Tahía; RINCÓN, Ana M.; LIMÓN, M. Carmen and CODON, Antonio C. Bioncontrol mechanisms of Trichoderma strains. International Microbiology, 2004, vol. 7, no. 4, p. 249-260.

BERG, Gabriele; ZACHOW, Christin; LOTTMANN, Jana; GÖTZ, Monika; COSTA, Rodrigo and SMALLA, Kornelia. Impact of plant species and site on rhizosphereassociated fungi antagonistic to Verticillium dahliae kleb. Applied and Environmental Microbiology, August 2005, vol. 71, no. 8, p. 4203-4213.

BESOAÍN, Ximena; PÉREZ, Luz Maria; ARAYA, Antonio; LEFEVER, Llacolén; SANGUINETTI, Melina and MONTEALEGRE, Jaime R. New strains obtained after UV treatment and protoplast fusion of native Trichoderma harzianum: their biocontrol effect on Pyrenochaeta lycopersici. Electronic Journal of Biotechnology, October 2007, vol. 10, no. 4, p. 604-617.

DENNIS, C. and WEBSTER, J. Antagonistic properties of species-groups of Trichoderma: III. Hyphal interaction. Transactions of the British Mycological Society, December 1971, vol. 57, no. 3, p. 363-369.

DRUZHININA, Irina S.; KOPCHINSKIY, Alex G. and KUBICEK, Christian P. The first 100 Trichoderma species characterized by molecular data. Mycoscience, April 2006, vol. 47, no. 2, p. 55-64.

GHINI, Raquel; HAMADA, Emília and BETTIOL, Wagner. Climate change and plant disease. Scientia Agricola, 2008, vol. 65, special issue, p. 98-107.

HAGGAG, W.M. and AMIN, A.W. Efficiency of Trichoderma species in control of Fusarium rot, root knot and reniform nematode disease complex on sunflower. Pakistan Journal of Biological Sciences, 2001, vol. 4, no. 6, p. 679-683.

HAGN, Alexandra; PRITSH, Karin; SCHLOTER, Michael and MUNCH, Jean Charles. Fungal diversity in agricultural soil under different farming management systems, with special reference to biocontrol strains of Trichoderma spp. Biology and Fertility of Soils, August 2003, vol. 38, no. 4, p. 236-244.

HOWELL, C. Mechanisms employed by Trichoderma species in the biological control of plant diseases: the 
history and evolutions of current concepts. Plant Disease, January 2003, vol. 87, no. 1, p. 4-10.

KAY, S.J. and STEWART, A. The effect of fungicides on fungal antagonisms of onion white rot and selection of dicarboximide-resistant biotypes. Plant Pathology, October 1994, vol. 43, no. 5, p. 863-871.

KNUDSEN, G.R. and BIN, L. Effects of temperature, soil moisture, and wheat bran on growth of Trichoderma harzianum from alginate pellets. Phytopathology, August 1990, vol. 80, no. 8, p. 724-727.

KREDICS, László; ANTAL, Zsuzsanna and MANCZINGER, Lázsló. Influence of water potential on growth, enzyme secretion and in vitro enzyme activities of Trichoderma harzianum at different temperatures. Current Microbiology, May 2000, vol. 40, no. 5, p. 310-314.

KREDICS, L.; ANTAL, Z.; MANCZINGER, L. and NAGY, E. Breeding of mycoparasitic Trichoderma strains for heavy metal resistance. Letters in Applied Microbiology, August 2001, vol. 33, no. 2, p. 112-116.

KREDICS, L.; MANCZINGER, L.; ANTAL, Z.; PÉNZES, Z.; SZEKERES, A.; KEVEI, F. and NAGY, E. In vitro water activity and $\mathrm{pH}$ dependence of mycelial growth and extracellular enzyme activities of Trichoderma strains with biocontrol potential. Journal of Applied Microbiology, March 2004, vol. 96, no. 3, p. 491-498.

KÜÇÜK, Ç. and KIVANÇ, M. Effect of formulation on the viability of biocontrol agent, Trichoderma harzianum conidia. African Journal of Biotechnology, June 2005, vol. 4, no. 6, p. 483-486.

LATORRE, Bernardo. Enfermedades de las plantas cultivadas. Santiago; Ediciones Universidad Católica de Chile. 2004. 638 p. ISBN 956-14-0756-6.

LIU, Bo; GLENN, Deborah and BUCKLEY, Katrina. Trichoderma communities in soils from organic, sustainable, and conventional farms, and their relation with Southern blight of tomato. Soil Biology and Biochemistry, May 2008, vol. 40, no. 5, p. 1124-1136.

MADIGAN, M.T.; MARTINKO, J.M. and PARKER, J. Brock biología de los microorganismos. $10^{\text {th }}$ Ed. Madrid; Pearson Educación S.A., 2003. 1096 p.

MONTEALEGRE, J. and LARENAS, C. Efecto de la temperatura de almacenaje y del contenido de nutrientes sobre la viabilidad de pellets de Trichoderma harzianum. Fitopatología, 1997, vol. 31, no. 1, p. 66-69.

MONTEALEGRE, J.; REYES, R.; BESOAÍN, X.; PÉREZ, L.M. and HERRERA, R. Identificación de grupos de anastomosis de cepas de Rhizoctonia solani Künh aisladas de tomates en la V Región Chile: (Rhizoctonia solani Künh anatomosis groups: identification of strains isolated from tomato crops at the V Region of Chile). Boletín Micológico, 2003, vol. 18, no. 2, p. 47-51.

MONTEALEGRE, Jaime; VALDERRAMA, Luis; HERRERA, Rodrigo; BESOAÍN, Ximena and PÉREZ, Luz María. Biocontrol of Rhizoctonia solani in tomatoes with Trichoderma harzianum mutants. IOBC/WPRS Bulletin, 2007, vol. 30, no. 6, p. 153-157.

MONTEALEGRE, J.; VALDERRAMA, L.; SANCHEZ, S.; HERRERA, R.; BESOAÍN, X. and PÉREZ, L.M. Biological control of Rhizoctonia solani in tomatoes with Trichoderma harzianum mutants. Electronic Journal of Biotechnology. In press, 2009.

NAÁR, Z. and KECSKÉS, M. Factors influencing the competitive saprophytic ability of Trichoderma species. Microbiological Research, 1998, vol. 153, no. 2, p. 119129.

NASEBY, D.C.; PASCUAL, J.A. and LYNCH, J.M. Effect of biocontrol strains of Trichoderma on plant growth, Pythium ultimum populations, soil microbiol communities and soil enzyme activities. Journal of Applied Microbiology, January 2000, vol. 88, no. 1, p. 161-169.

ORR, K.A. and KNUDSEN, G.R. use of green fluorescent protein and image analysis to quantify proliferation of Trichoderma harzianum in nonsterile soil. Phytopathology, December 2004, vol. 94, no. 12, p. 1383-1389.

PÉREZ, Luz María; BESOAÍN, Ximena; REYES, Mauricio; PARDO, Gonzalo and MONTEALEGRE, Jaime. The expression of extracellular fungal cell wall hydrolytic enzymes by different Trichoderma harzianum isolates correlates with their ability to control Pyrenochaeta lycopersici. Biological Research, 2002, vol. 35, no. 3-4, p. 401-410.

PÉREZ, Luz María; POLANCO, Rubén; RIOS, Juan C.; MONTEALEGRE, Jaime; VALDERRAMA, Luis; HERRERA, Rodrigo and BESOAÍN, Ximena. The increase in endochitinases and $\beta$-1,3-glucanases in the mutant Th650-NG7 of the Trichoderma harzianum Th650, improves the biocontrol activity on Rhizoctonia solani infecting tomato. IOBC/WPRS Bulletin, 2007, vol. 30, no. 6, p. 135-138.

SHABAN, Gehan M. and EL-KOMY, Hesham M.A. Survival and proliferation of alginate encapsulated Trichoderma spp. in Egyptian soil in comparison with allyl alcohol soil fumigation. Mycopathologia, September 2000, vol. 151, no. 3, p. 139-146.

SHISHKOFF, N. and CAMPBELL, R. Survival of Pyrenochaeta lycopersici and the influence of temperature and cultivar resistance on the development of corky root of tomato. Plant Disease, November 1990, no. 11, vol. 74, p. 889-894. 
STRASHNOW, Y.; ELAD, Y.; SIVAN, A. and CHET, I. Integrated control of Rhizoctonia solani by methyl bromide and Trichoderma harzianum. Plant Pathology, March 1985, vol. 34, no. 1, p. 146-151.

WILLIAMS, Josie; CLARKSON, John M.; MILLS, Peter R. and COOPER, Richard M. A selective medium for quantitative reisolation of Trichoderma harzianum from Agaricus bisporus compost. Applied and Environmental Microbiology, July 2003, vol. 69, no. 7, p. 4190-4191. 